\title{
Multiple biomarker responses in caged benthic gastropods Bellamya aeruginosa after in situ exposure to Taihu Lake in China
}

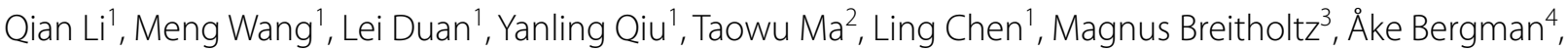 \\ Jianfu Zhao ${ }^{1}$, Markus Hecker ${ }^{5}$ and Lingling Wu W $^{1,5^{*}}$
}

\begin{abstract}
Background: Freshwater sediments have been recognized as a long-term sink and potential source for environmental pollutants released into the aquatic ecosystems. In this study, the sediment quality of Taihu Lake, which is susceptible to anthropogenic contamination, was assessed by a combination of chemical analytical and biological end points. Specifically, the snail Bellamya aeruginosa was caged in situ at two locations representing different pollution levels for different exposure times (7, 14 and 21 days). At each of these time points, biochemical parameters, i.e., phase I biotransformation enzymes ethoxyresorufin-O-deethylase (EROD), the antioxidant enzymes superoxide dismutase and catalase, reactive oxygen species, protein carbonyl content and lipid peroxidation, were evaluated in the hepatopancreas of snails. In addition, surface sediments were collected for analysis of contaminants of concern, including inorganic pollutants, organochlorine pesticides, polychlorinated biphenyls and polybrominated diphenyl ethers.

Results: Chemical analyses revealed that sediments from Taihu Lake were contaminated with trace elements and organic pollutants. Concentrations of trace elements ( $\mathrm{Cu}, \mathrm{Ni}$ and $\mathrm{As})$ and organochlorinated pesticides (4,4'-DDE) exceeded their corresponding threshold effect level according to the sediment quality assessment values for freshwater ecosystems in Canada, indicating that adverse biological effects may occur. All biomarkers, except EROD activity, were induced in snails during all exposure times. The integrated biomarker response index (IBR) indicated that during the initial exposure phase (7 days), B. aeruginosa were subjected to significant environmental stress, which diminished during later sampling time points.
\end{abstract}

Conclusions: Results showed that IBR correlated well with the levels of environmental contaminants, demonstrating the applicability of this biomonitoring approach to complex environmental exposure scenarios.

Keywords: Freshwater sediment, Bellamya aeruginosa, Caged organisms, Biomonitoring

\section{Background}

In recent years, water quality of many freshwater lakes has been shown to progressively deteriorate with the rapid economic growth in many developing countries. Main contributors to the contamination of lake ecosystems are runoff from agricultural activities and industrial and municipal effluents $[1,2]$. Sediments are important

\footnotetext{
${ }^{*}$ Correspondence: wulingling@tongji.edu.cn

1 State Key Laboratory of Pollution Control and Resource Reuse,

College of Environmental Science and Engineering, Tongji University,

Shanghai 200092, China

Full list of author information is available at the end of the article
}

components of the aquatic environment and constitute a particular concern from an environmental toxicology perspective, as they can retain persistent and toxic chemicals at levels many times greater than concentrations typically found in the water column [3]. Contaminated sediments may pose direct threats to benthic biota and to organisms that feed on the benthos $[4,5]$. Therefore, characterization of sediment quality is of great relevance for the risk assessment of contaminant to aquatic ecosystems and potential human health. There are several tools for the assessment of sediment quality, including routine chemical analyses and sediment toxicity biological 
assays or tests [6]. Toxicity tests have been proven to be highly useful and relevant as they can often be done more quickly and inexpensively compared to chemical analyses and can provide insights into the effect of sedimentbound chemicals on organisms [7].

Field toxicity tests using caged organisms present numerous advantages over laboratory toxicity testing and indigenous community surveys [8]. In situ caging experiments involving organisms such as fish $[9,10]$, bivalves [11-13], crustaceans [14, 15], gastropods [16, 17], polychaetes [18] and oligochaetes [19] capture the complex interactions and more realistic exposure conditions compared to laboratory tests [8]. Furthermore, compared with studies of native populations, the use of caged organisms affords numerous advantages such as the ability to select specific species and developmental stages, to control exposure duration and to focus on specific locations as animals are prevented from moving into or out of sites [20]. In addition, the use of caged organisms can minimize the influence of adaptive mechanisms, which may have evolved in resident organisms over time under long-term chronic exposure conditions and would lead to the underestimation of pollution [14].

Benthic gastropods are essential members of aquatic systems and relatively sensitive to contaminants [21]. Bellamya aeruginosa (synonym: Sinotaia aeruginosa; Gastropoda, Caenogastropoda, Viviparidae) is commonly found in various freshwater habitats of lakes (including Taihu Lake), reservoirs, rivers, streams, ditches and ponds throughout China. This species is a dominant community member of freshwater aquatic systems [22] and it is therefore an ecologically important representative of benthic macroinvertebrates. As a deposit-feeding gastropod, B. aeruginosa ingests sediment particles, organic detritus, algae and bacteria on the surface of sediments or other substrates [23] and, therefore, it is highly susceptible to be exposed to sediment-associated contaminants. This species has been found to accumulate contaminants and to be sensitive to sediment-borne pollutants at the biochemical level [22, 24]. B. aeruginosa is a primary food item of the black carp (Mylopharyngodon piceus), which is also consumed by humans. Therefore, it represents a key organism involved with the transfer of contaminants through the food web in Chinese surface waters and, thus, it can be recommended as a key organism in the assessment of contaminant risks to ecosystems in China.

The impacts of sediment contamination on biota can be determined by the measurement of biomarkers [18]. Biomarkers can provide sensitive and biologically relevant information and can serve as an integrative measure of the effects of mixtures of chemical stressors [25, 26]. Another advantage of using biomarkers lies in their potential to anticipate damage at higher levels of biological organization before ecological disruption occurs [27]. Since there is no single biomarker that can reflect the overall health status of organisms, it has been recommended that a battery of biomarkers should be used to understand the adaptive responses to environmental conditions [27, 28]. Common biomarker end points that are often observed under complex environmental exposure scenarios include impacts on metabolic systems involved in detoxification of xenobiotics as well as antioxidant responses and oxidative stress. The activity of EROD (ethoxyresorufin-O-deethylase) represents the activity of the phase I biotransformation enzyme, cytochrome P4501A (CYP1A), which is essential for detoxification and excretion of chemicals. Measurements of ROS (reactive oxygen species) production and antioxidant defense in invertebrates are also applied widely for monitoring of pollution of aquatic environments [29, 30]. Many pollutants exert their effects through redox cycling, resulting in the production of ROS [10]. ROS can be detoxified by the antioxidant defense system including the SOD (superoxide dismutase) and CAT (catalase) enzymes. The imbalance between production of ROS and antioxidant defenses may lead to oxidative stress manifested as oxidative damage of lipids and proteins [31]. To integrate the responses of different biomarkers into a single value or graph, the methodology of the integrated biomarker response (IBR), described by Beliaeff and Burgeot [32], is widely used in field and laboratory studies [33, 34]. The second version for the index (IBRv2) was proposed based on the reference deviation concept to avoid the weakness of the first version by Sanchez et al. [35].

Taihu Lake, located in the delta region of the Yangtze River, is the third largest freshwater lake in China and an important drinking water source for surrounding cities $[36,37]$. With rapid economic development and population increase in the Yangtze River Delta, untreated wastewater from plants and mills was directly discharged into rivers during the past decades and ultimately entered the lake, resulting in serious pollution of Taihu Lake $[38,39]$. Contaminants commonly found in Taihu Lake include trace metals [40] and organic contaminants such as organochlorinated pesticides (OCPs), polychlorinated biphenyls (PCBs) and polybrominated biphenyl ethers (PBDEs) [1, 41, 42], which pose potential threats to resident aquatic organisms.

In this study, caged snails were employed to assess sediment quality in the eastern part of Taihu Lake. The objectives were (1) to determine the suitability of a battery of biochemical biomarkers analyzed in caged $B$. aeruginosa as a tool to assess exposure to contaminated sediments under field conditions; and (2) to evaluate the sediment quality of Taihu Lake using a combination of chemical 
analysis and in vivo toxicity assessments. Specifically, the battery of biomarkers utilized by this study consisted of activities of EROD, antioxidant enzymes including superoxide dismutase (SOD) and catalase (CAT), reactive oxygen species (ROS), the protein carbonyl content (PCC) and lipid peroxidation (LPO). Finally, levels of trace metals, OCPs, PCBs and PBDEs were investigated in sediments of the lake.

\section{Methods}

\section{Chemicals and reagents}

Reference standards of OCPs, including 2,4'-dichlorodiphenyldichloroethylene (2,4'-DDE), 2,4'-dichlorodiphenyldichloroethane (2,4'-DDD), 4,4'-dichlorodiphenyltrichloroethane (4,4'-DDT), 4,4'-dichlorodiphenyldichloroethylene $\quad\left(4,4^{\prime}-\right.$ $\mathrm{DDE}), \quad 4,4^{\prime}$-dichlorodiphenyldichloroethane (4,4'-DDD), alfa-hexachlorocyclohexane $(\alpha-\mathrm{H}-\mathrm{CH})$, beta-hexachlorocyclohexane $(\beta-\mathrm{HCH})$, gamma-hexachlorocyclohexane $(\gamma-\mathrm{H}-\mathrm{CH})$, delta-hexachlorocyclohexane $(\delta-\mathrm{HCH})$, aldrin, hexachlorobenzene $(\mathrm{HCB})$, pentachloroaniline $(\mathrm{PCA})$, dieldrin, $\alpha$-endosulfan, $\beta$-endosulfan, endrin, heptachlor, cisheptachlor epoxide, trans-heptachlor epoxide, methoxychlor and mirex were purchased as a mixture from AccuStandard (New Haven, USA).

The PCB congeners including CB-18, 28, 31, 44, 52, $101,118,138,149,153,170,180,194$ and 209 were also purchased from AccuStandard (New Haven, USA). PBDE congeners: BDE-28, 47, 66, 99, 100, 153, 154 and 183 were bought as a mixture from Wellington Laboratories Inc. (Guelph, Ontario, Canada). A mixture with octa- to deca-BDEs (BDE-194, 195, 196,197, 198, 199, 200, 201, 202, 203, 204, 205, 206, 207, 208 and 209) was also bought from Wellington Laboratories Inc. (Guelph, Ontario, Canada). Methoxylated polybrominated diphenyl ethers (MeO-PBDEs) congeners, including 2-MeO-BDE68 and 2-MeO-BDE47, were purchased from AccuStandard (New Haven, USA). All solvents used for sample processing and analyses were of pesticide grade.

\section{Test species}

Adults of $B$. aeruginosa were obtained from clean sediments of artificial ponds in Wuhan Botanic Garden (Wuhan, China) and selection of the correct species was confirmed taxonomically [43]. Before initiation of the caging experiments, the snails were acclimatized for more than 3 months in clean glass tanks in the laboratory. During the acclimation, the culture conditions were set based on natural habitat conditions. The ratio of sediments to water was 1:4 and the photoperiod was set at a $12 \mathrm{~h}$ light and $12 \mathrm{~h}$ dark cycle. The snails were kept in tanks at a water temperature of $24 \pm 1{ }^{\circ} \mathrm{C}$, a hardness of $250 \mathrm{mg} / \mathrm{L}$, a pH value of $7.5 \pm 0.5$ and a dissolved oxygen concentration of $10.5 \pm 0.5 \mathrm{mg} / \mathrm{L}$. The water was charcoal filtered and dechlorinated tap water. The sediments were prepared with unpolluted terrestrial soil, which were collected from an uncultivated plot at Dehang Nature Reserve, Jishou, China [22]. The concentrations of trace metals and organic pollutants in sediments are listed in Additional file 1: Table S1. B. aeruginosa were fed with commercial aquarium fish food (Sanyuan ${ }^{\circledR}$, Beijing, China) [22]. After acclimation, a group of snails $(n=120)$ was sampled for the verification of baseline levels of biomarkers for this species, and as no significant difference was detected among baseline levels determined for this group. This group was named basal group (Control). 720 snails were transported to the selected experimental sites in plastic bags containing water and oxygen for the caging exposure tests. Snails with an average shell length of $20.00 \pm 1.68 \mathrm{~mm}$ and average body weight of $2.05 \pm 0.20 \mathrm{~g}$ were used in the experiments. The experiments were conducted in accordance with the Animal Ethics Committee at Tongji University.

\section{Study sites}

In situ exposure tests were performed at two experimental sites in Taihu Lake, site A $\left(31^{\circ} 13^{\prime} 51^{\prime \prime} \mathrm{N}-120^{\circ} 22^{\prime} 7^{\prime \prime} \mathrm{E}\right)$ and site $\mathrm{B}\left(31^{\circ} 6^{\prime} 2^{\prime \prime} \mathrm{N}-120^{\circ} 13^{\prime} 55^{\prime \prime} \mathrm{E}\right)$ (Fig. 1). Site A was located in the eastern area of Taihu Lake in proximity to the water quality and cyanobacterial field multi-observation station for Taihu Lake in Jiangsu province. Pollutants produced by industry and agriculture were mainly from the east of the lake basin, such as Suzhou City. The eastern area is the major outlet of Taihu Lake and is mostly covered with macrophytes which reduce water flow velocity and increase sedimentation rates [44]. Site $\mathrm{B}$ was located at Xishan Island in the central lake area. This island has been developed for tourism for several decades, so many vessels for fishery and tourism were built, which have caused pollution in this area. The average water depth of the two sites in Taihu Lake is about 2.0 $\mathrm{m}$. In some previous studies, a reference site was selected in comparatively uncontaminated environment $[12,45]$. However, it is scarcely possible to find such a clean freshwater area without anthropogenic pollutants in China, thus the basal group was determined as the control group following other studies $[10,27,46]$.

\section{Caging exposure}

Caged snail exposure tests were conducted for 21 days during August 2015. Cylindrical cages (0.26 m height, $0.80 \mathrm{~m}$ diameter, $130 \mathrm{~L}$ volume) composed of nylon mesh $(3 \mathrm{~mm})$ and a polypropylene baffle were used for the exposures. At each site, three cages, containing 120 snails each, were immersed into the water and fixed in direct contact with the sediments. One cage from each site was sampled each after 7, 14 and 21 days, respectively, and 


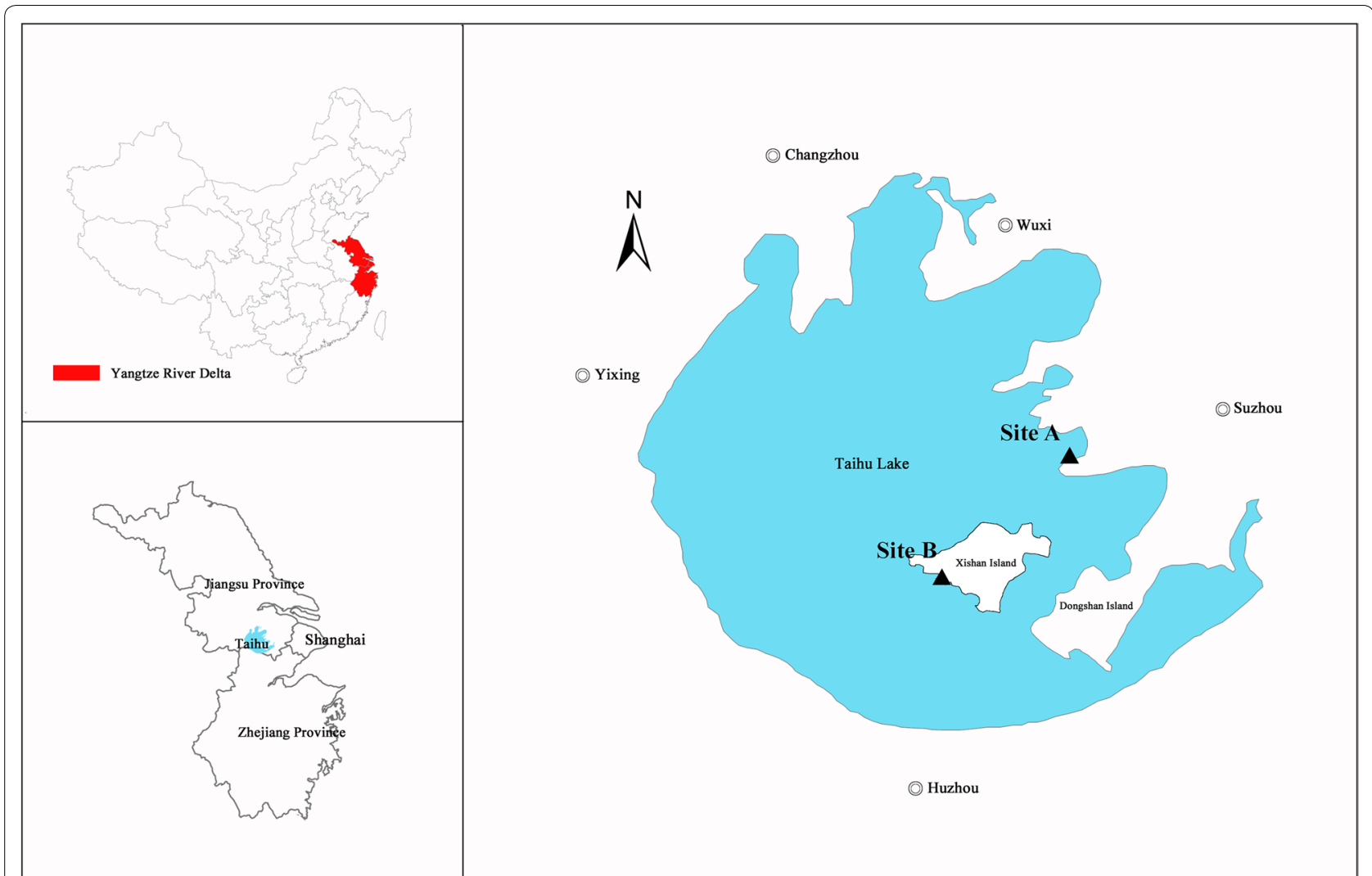

Fig. 1 Location of the Yangtze River Delta in China and caging sites in Taihu Lake (solid triangles represent caging sites A and B; double circles around the lake are major cities with population over one million)

surviving organisms were counted. A subset of snails was immediately frozen in liquid nitrogen for biochemical analysis. However, one cage located at site A disappeared unexpectedly for unknown reasons after 21 day of exposure, and thus it was impossible to recover the snails from this cage. The caged snail samples exposed for 7 and 14 days, and 7, 14 and 21 days at sites A and B were defined as $A_{7}$ and $A_{14}$, and $B_{7}, B_{14}$ and $B_{21}$, respectively. Water quality parameters, including temperature, $\mathrm{pH}$ and dissolved oxygen, were measured during the caging exposure by the Jiangsu water quality and cyanobacteria field multi-observation station for Taihu Lake.

\section{Sediment sampling and chemical analysis}

Surface sediment samples (0 to $5 \mathrm{~cm}$ depth) were collected from each caging site at the beginning of the encaged experiment using a Van Veen grab and were brought to the laboratory immediately. Sediments were freeze-dried, homogenized, ground and sieved with a 200-mesh nylon screen and kept below $-20{ }^{\circ} \mathrm{C}$ until chemical analysis.

\section{TOC content}

Total organic carbon (TOC) contents of the sieved and freeze-dried sediments were determined using a total organic carbon analyzer (TOC-VCPN, Shimadzu, Japan).

\section{Trace elements}

The sieved and freeze-dried samples $(0.2 \mathrm{~g})$ were microwave digested in Teflon vessels using a mixture of concentrated $\mathrm{HNO}_{3}, \mathrm{HCl}$ and $\mathrm{HF}$ according to the EPA Method 3052 [47]. $\mathrm{HClO}_{4}$ was added to remove $\mathrm{HF}$ and then adjusted to a volume of $10.0 \mathrm{~mL}$ with $2 \%(\mathrm{v} / \mathrm{v})$ $\mathrm{HNO}_{3}$ before instrumental analysis [48]. Target elements $(\mathrm{Cr}, \mathrm{Cu}, \mathrm{Pb}, \mathrm{Ni}, \mathrm{Zn}, \mathrm{Cd}, \mathrm{As})$ were analyzed using inductively coupled plasma atomic emission spectroscopy (ICP-AES, Agilent 720 ES, USA). Recovery rates of the analytical procedures were assessed using a standard reference material (SRM 1646a, National Institute of Standards and Technology), and all elements showed a recovery greater than $90 \%$ of the certified concentration. 


\section{Organic pollutants}

The procedures for the extraction and purification of organochlorine pesticides (OCPs), polychlorinated biphenyls (PCBs) and polybrominated diphenyl ethers (PBDEs) have been published in detail elsewhere [4952]. So the methods for extraction, clean up, analysis and quality assurance and quality control are described in Additional file 1: Text S1.

\section{Biochemical markers}

Thirty snails from each cage were dissected and their hepatopancreas was removed for biomarker determination. Hepatopancreas tissue was weighed and homogenized $(1: 4 \mathrm{w} / \mathrm{v})$ in ice-cold Tris- $\mathrm{HCl}$ buffer $(0.01 \mathrm{M}$, $\mathrm{pH} 7.4$ ) and $1.0 \mathrm{mM}$ phenylmethylsulfonyl fluoride as a serine protease inhibitor using a glass homogenizer. The homogenates were centrifuged at $1000 \times g$ for $10 \mathrm{~min}$ at $4{ }^{\circ} \mathrm{C}$ and the section of supernatants was collected for determination of protein carbonyl content. The remaining content was continuously centrifuged at $9000 \times g$ for $20 \mathrm{~min}$ at $4{ }^{\circ} \mathrm{C}$ and the resulting supernatant was separated for the analysis of other biochemical parameters. Total protein concentrations were determined with the total protein kit (Sigma-Aldrich, USA) based on the Bradford method [53]. All biomarker responses were detected using BioTek Synergy 4 multi-mode microplate reader (BioTek, USA).

\section{Ethoxyresorufin-O-deethylase (EROD) activity}

EROD activity of the supernatant (S9 fraction) was measured following the hydroxylation of 7-ethoxyresorufin according to the method of Burke and Mayer [54] as adapted by Pacheco and Santos [55]. The reaction mixture consists of $950.0 \mu \mathrm{L}$ phosphate-buffered saline (PBS, pH 7.8; Sigma, USA), $10.0 \mu \mathrm{L}$ of $0.1 \mathrm{mM}$ ethoxyresorufin (ERF; Sigma-Aldrich, USA), $30.0 \mu \mathrm{L}$ of $1.0 \mathrm{mM}$ NADPH (Aladdin, USA) and $10.0 \mu \mathrm{L}$ prepared hepatopancreas homogenate supernatant sample. Determination of enzyme activity of each sample was carried out by measuring the end product resorufin (RF) of the catalytic reaction using the fluorescence multi-well plate reader (BioTek, USA) at excitation wavelength $530 \mathrm{~nm}$ and emission wavelength $585 \mathrm{~nm}$. Enzyme activity was calculated as $\mathrm{pmol} / \mathrm{min} / \mathrm{mg}$ protein using a standard curve of resorufin.

\section{Reactive oxygen species (ROS) production}

ROS (superoxide and hydroxyl radicals) were detected with the Fluorometric Intracellular ROS Assay Kit (Sigma-Aldrich, USA) following the manufacturer's protocol using fluorometric sensors localized to the cytoplasm, resulting in a fluorometric product proportional to the amount of ROS present. The fluorescence intensity was determined at $\lambda \mathrm{ex}=540 \mathrm{~nm}$ and $\lambda \mathrm{em}=570 \mathrm{~nm}$. Fold increases in ROS levels were determined by comparison with the control group.

\section{Antioxidant enzymes}

SOD activity was determined by the SOD assay kit (Sigma-Aldrich, USA). SOD activity was quantified by measuring the decrease in the color development at $440 \mathrm{~nm}$ with a colorimetric method, which is proportional to the amount of superoxide anion. Results were expressed as the inhibition rate (\%) of the reduction with molecular oxygen.

Changes in CAT activity were evaluated by the catalase assay kit (Sigma-Aldrich, USA). CAT activity was quantified by measuring the hydrogen peroxide substrate remaining after reaction for $15 \mathrm{~min}$ by an absorbance spectrophotometer at $520 \mathrm{~nm}$. Results were expressed as $\mathrm{mmole} / \mathrm{min} / \mathrm{mL}$.

\section{Oxidative stress}

LPO was determined by the lipid peroxidation assay kit (Sigma-Aldrich, USA) by measuring the colorimetric product $(532 \mathrm{~nm})$ formed by the reaction of malondialdehyde (MDA) with thiobarbituric acid (TBA) and which is proportional to the concentration of MDA present. Results were expressed as nmole $/ \mu \mathrm{L}$.

PCC assay kit (Sigma-Aldrich, USA) was applied to detect the production of stable carbonyl groups induced by oxidative stress. Carbonyl content was determined by the derivatization of protein carbonyl groups with 2,4-dinitrophenylhydrazine (DNPH) leading to the formation of stable dinitrophenyl (DNP) hydrazone adducts, which can be detected spectrophotometrically at $375 \mathrm{~nm}$, proportional to the carbonyls present. Results were expressed as nmole/mg protein.

\section{Integrated biomarker response index (IBR)}

The biomarker results were applied into the "Integrated Biomarker Response Index" (IBRv2) described by Beliaeff and Burgeot [32] and modified by Sanchez et al. [35]. This novel version of IBR is based on the principle of reference deviation between a disturbed and undisturbed state [35]. In the present study, the deviation between biomarkers measured in snails caged at site A and site B were compared to those measured in snails acclimated in the sediments under controlled laboratory conditions (baseline levels). The baseline values of each biomarker $\left(X_{0}\right)$ were used as a reference value.

For each individual biomarker, the ratio between the mean value $\left(X_{i}\right)$ obtained at each caging site and the respective mean baseline $\left(X_{0}\right)$ was log-transformed $\left(Y_{i}\right)$ (Eq. 1): 


$$
Y_{i}=\log \left(X_{i} / X_{0}\right) .
$$

In the next step, the general mean $(\mu)$ and standard deviation $(s)$ of $Y_{i}$ were computed. Then, $Y_{i}$ values were standardized by the formula (Eq. 2):

$$
Z_{i}=\left(Y_{i}-\mu\right) / s \text {. }
$$

The differences between the mean of standardized biomarker response $\left(Z_{i}\right)$ and mean of reference biomarker data $\left(Z_{0}\right)$ were used to define the biomarker deviation index $(A)$ (Eq. 3):

$$
A=Z_{i}-Z_{0} .
$$

Finally, the integrated multiple biomarkers response index (IBR) of the caged snails in each caging site was obtained by summarizing the absolute value of $A$ parameters for each biomarker.

\section{Statistical analysis}

Statistical analysis of data was carried out by SPSS 19.0. Biomarker results were tested for normality and homogeneity of variance with the Shapiro-Wilks and Levene test, respectively. Analysis of variance (ANOVA) followed by a Dunnett's test was used to compare the biomarkers obtained in snails from the two caging sites after different exposure times with those obtained in snails acclimated in the laboratory. The significance level was set at $p<0.05$.

\section{Results}

\section{Physical and chemical analysis of water and sediments}

There were no differences in water quality between the two sampling sites, with water temperatures of 26.8$33.1{ }^{\circ} \mathrm{C}, \mathrm{pH}$ of $8.2-8.7$ and dissolved oxygen (DO) concentrations of $6.57-9.16 \mathrm{mg} / \mathrm{L}$.

Chemical characterization of the sediment samples from the caging sites identified 7 trace elements and 55 organic compounds (21 OCPs, 11 PCBs and 23 PBDEs) (Table 1). With the exception of PBDEs, concentrations of metals and other organic pollutants were markedly greater at site $\mathrm{A}$ when compared to site $\mathrm{B}$.

\section{Individual mortality}

The survival rates decreased with the increasing exposure time at both sites (Fig. 2). The survival rate of caged snails at site A decreased to $78.9 \%$ after exposure for 14 days, which was slightly lower than the survival rate of snails caged at site B $(82.5 \%)$. The survival rate for site B was reduced to $73.3 \%$ after 21 days of exposure.

\begin{tabular}{|c|c|c|c|c|c|}
\hline \multicolumn{2}{|l|}{ Parameters } & \multirow{2}{*}{$\begin{array}{c}\text { Site A } \\
0.77\end{array}$} & \multirow{2}{*}{$\begin{array}{c}\text { Site B } \\
1.29\end{array}$} & \multirow[t]{2}{*}{$\mathrm{TEL}^{\mathrm{a}}$} & \multirow[t]{2}{*}{$\mathrm{PEL}^{\mathbf{b}}$} \\
\hline TOC (\%) & & & & & \\
\hline \multirow{7}{*}{$\begin{array}{l}\text { Metals (mg/ } \\
\text { kg) }\end{array}$} & $\mathrm{Cr}$ & 34.17 & 28.99 & 37.30 & 90.00 \\
\hline & $\mathrm{Cu}$ & 39.49 & 17.72 & 35.70 & 197.00 \\
\hline & $\mathrm{Pb}$ & 24.15 & 23.85 & 35.00 & 91.30 \\
\hline & $\mathrm{Ni}$ & 21.40 & 16.89 & 18.00 & 36.00 \\
\hline & $\mathrm{Zn}$ & 99.00 & 62.47 & 123.00 & 315.00 \\
\hline & $\mathrm{Cd}$ & 0.20 & 0.16 & 0.60 & 3.53 \\
\hline & As & 6.77 & 5.04 & 5.90 & 17.00 \\
\hline \multirow{5}{*}{$\begin{array}{l}\text { OCPs-DDTs } \\
\text { (ng/g dw) }\end{array}$} & $2,4^{\prime}-\mathrm{DDD}$ & 0.36 & 0.01 & & \\
\hline & $2,4^{\prime}-\mathrm{DDE}$ & 0.001 & 0.13 & & \\
\hline & $4,4^{\prime}-\mathrm{DDD}$ & 0.001 & 0.04 & 3.54 & 8.51 \\
\hline & $4,4^{\prime}-\mathrm{DDE}$ & 3.45 & 1.68 & 1.42 & 6.75 \\
\hline & $4,4^{\prime}-\mathrm{DDT}$ & 0.45 & 0.13 & & \\
\hline \multirow{4}{*}{$\begin{array}{r}\text { OCPs-HCHs } \\
\text { (ng/g dw) }\end{array}$} & $\mathrm{a}-\mathrm{HCH}$ & 0.001 & 0.01 & & \\
\hline & $\beta-\mathrm{HCH}$ & 0.54 & 0.01 & & \\
\hline & $\gamma-\mathrm{HCH}$ & 0.64 & 0.04 & 0.94 & 1.38 \\
\hline & $\delta-\mathrm{HCH}$ & 32.03 & 0.001 & & \\
\hline \multirow{12}{*}{$\begin{array}{r}\text { Other OCPs } \\
\text { (ng/g dw) }\end{array}$} & Aldrin & 0.001 & 0.001 & & \\
\hline & $\mathrm{HCB}$ & 0.001 & 0.06 & & \\
\hline & PCA & 0.57 & 0.01 & & \\
\hline & Diedrin & 1.15 & 0.01 & & \\
\hline & a-Endosulfan & 0.001 & 0.01 & & \\
\hline & $\beta$-Endosulfan & 0.001 & 0.001 & & \\
\hline & Endrin & 0.001 & 0.01 & 2.67 & 62.4 \\
\hline & Heptachlor & 0.001 & 0.001 & & \\
\hline & $\begin{array}{l}\text { cis-heptachlor } \\
\text { epoxide }\end{array}$ & 0.001 & 0.01 & & \\
\hline & $\begin{array}{l}\text { trans-heptachlor } \\
\text { epoxide }\end{array}$ & 0.001 & 0.02 & & \\
\hline & Methoxychlor & 1.32 & 0.001 & & \\
\hline & Mirex & 0.001 & 0.05 & & \\
\hline \multirow{11}{*}{$\begin{array}{l}\text { PCBs (ng/g } \\
\text { dw) }\end{array}$} & CB18 & 3.43 & 0.13 & & \\
\hline & CB31+28 & 3.10 & 0.02 & & \\
\hline & CB44 & 9.31 & 0.02 & & \\
\hline & CB52 & 0.001 & 0.03 & & \\
\hline & CB101 & 0.001 & 0.001 & & \\
\hline & CB138 & 0.21 & 0.05 & & \\
\hline & CB153 & 0.84 & 0.001 & & \\
\hline & CB180 & 0.54 & 0.05 & & \\
\hline & CB183 & 0.001 & 0.03 & & \\
\hline & CB194 & 0.33 & 0.02 & & \\
\hline & CB209 & 0.001 & 0.001 & & \\
\hline
\end{tabular}

Table 1 Chemical analysis of surface sediments collected from the caging sites $A$ and $B$ in the Taihu Lake 
Table 1 (continued)

\begin{tabular}{|c|c|c|c|c|c|}
\hline Parameters & & Site A & Site B & $\mathrm{TEL}^{\mathrm{a}}$ & $\mathrm{PEL}^{\mathbf{b}}$ \\
\hline \multirow{23}{*}{$\begin{array}{l}\text { PBDEs (ng/g } \\
\text { dw) }\end{array}$} & BDE85 & 0.001 & 0.001 & & \\
\hline & BDE154 & 0.000 & 0.01 & & \\
\hline & BDE153 & 0.01 & 0.01 & & \\
\hline & BDE183 & 0.02 & 0.01 & & \\
\hline & BDE202 & 0.001 & 0.001 & & \\
\hline & BDE201 & 0.02 & 0.01 & & \\
\hline & BDE204 & 0.001 & 0.001 & & \\
\hline & BDE197 & 0.001 & 0.01 & & \\
\hline & $\begin{array}{l}\text { BDE }(198+ \\
199+ \\
200+203)\end{array}$ & 0.000 & 0.000 & & \\
\hline & BDE196 & 0.03 & 0.01 & & \\
\hline & BDE205 & 0.000 & 0.01 & & \\
\hline & BDE194 & 0.02 & 0.04 & & \\
\hline & BDE195 & 0.001 & 0.15 & & \\
\hline & BDE208 & 0.07 & 0.02 & & \\
\hline & BDE207 & 0.001 & 0.02 & & \\
\hline & BDE206 & 0.14 & 0.03 & & \\
\hline & BDE209 & 0.35 & 0.36 & & \\
\hline & BDE47 & 0.001 & 0.01 & & \\
\hline & BDE66 & 0.01 & 0.001 & & \\
\hline & 2-MeO-BDE68 & 0.001 & 0.001 & & \\
\hline & 2-MeO-BDE47 & 0.001 & 0.001 & & \\
\hline & BDE100 & 0.001 & 0.001 & & \\
\hline & BDE99 & 0.001 & 0.01 & & \\
\hline $\begin{array}{l}\sum D D T s \\
\quad(n g / g d w)\end{array}$ & & 4.26 & 1.99 & 7.00 & 4450.00 \\
\hline $\begin{array}{l}\Sigma O C P s \\
\quad(n g / g d w)\end{array}$ & & 40.50 & 2.22 & & \\
\hline $\begin{array}{l}\sum P C B s(n g / g \\
d w)\end{array}$ & & 17.76 & 0.35 & 34.1 & 277 \\
\hline $\begin{array}{l}\sum \text { PPBEs } \\
\quad(\mathrm{ng} / \mathrm{g} d w)\end{array}$ & & 0.67 & 0.71 & & \\
\hline
\end{tabular}

Detected concentrations are presented in plain type. Values in italic type mean not detected and are presented by limit of detection (LOD). Dw dry weight

a Threshold effect level (Smith et al. [56])

b Probable effect level (Smith et al. [56])

\section{Biomarkers}

\section{Detoxification metabolism}

With regard to EROD activity, there was a significant increase only in snails caged at the site B after 7 days $(p<0.01)$, while no significant differences were observed between snails confined at the site A compared with the control group (Fig. 3).

\section{Reactive oxygen species}

The levels of ROS in the hepatopancreas of caged snails at both sites A and B showed a time-dependent and significant increase compared to snails from the control group (Fig. 4a). Specifically, ROS levels in snails from site

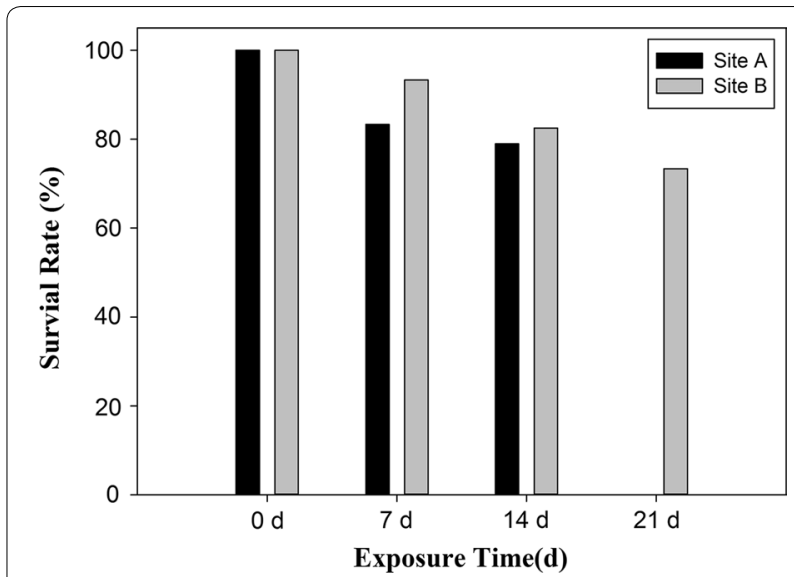

Fig. 2 Survival rate (\%) of Bellamya aeruginosa caged at sites A and B during the caging exposure in Taihu Lake

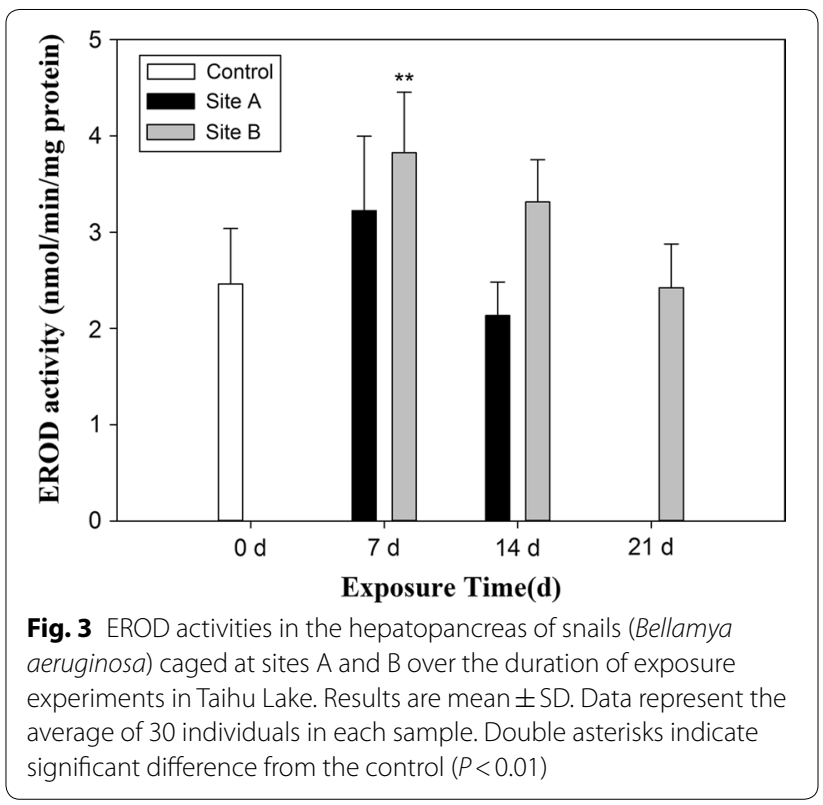

A increased to approximately three times that of those measured in the controls after 14 days of exposure. Maximum increases of ROS in snails from site B were 1.8-fold relative to controls and were significantly less than the levels in animals exposed at site A $(p<0.05)$.

\section{Antioxidant defenses}

Significant and time-dependent increases in activities of antioxidant enzymes were observed in snails exposed at both sampling sites (Fig. 4b, c). SOD activities increased linearly with exposure time at sites A $(p<0.05$; Fig. $4 \mathrm{~b})$ and B $(p<0.01$; Fig. $4 \mathrm{~b})$. CAT activities of caged snails at both sites $\mathrm{A}$ and $\mathrm{B}$ were also significantly increased at all exposure times compared with the control group $(p<0.01$; Fig. 4c). 


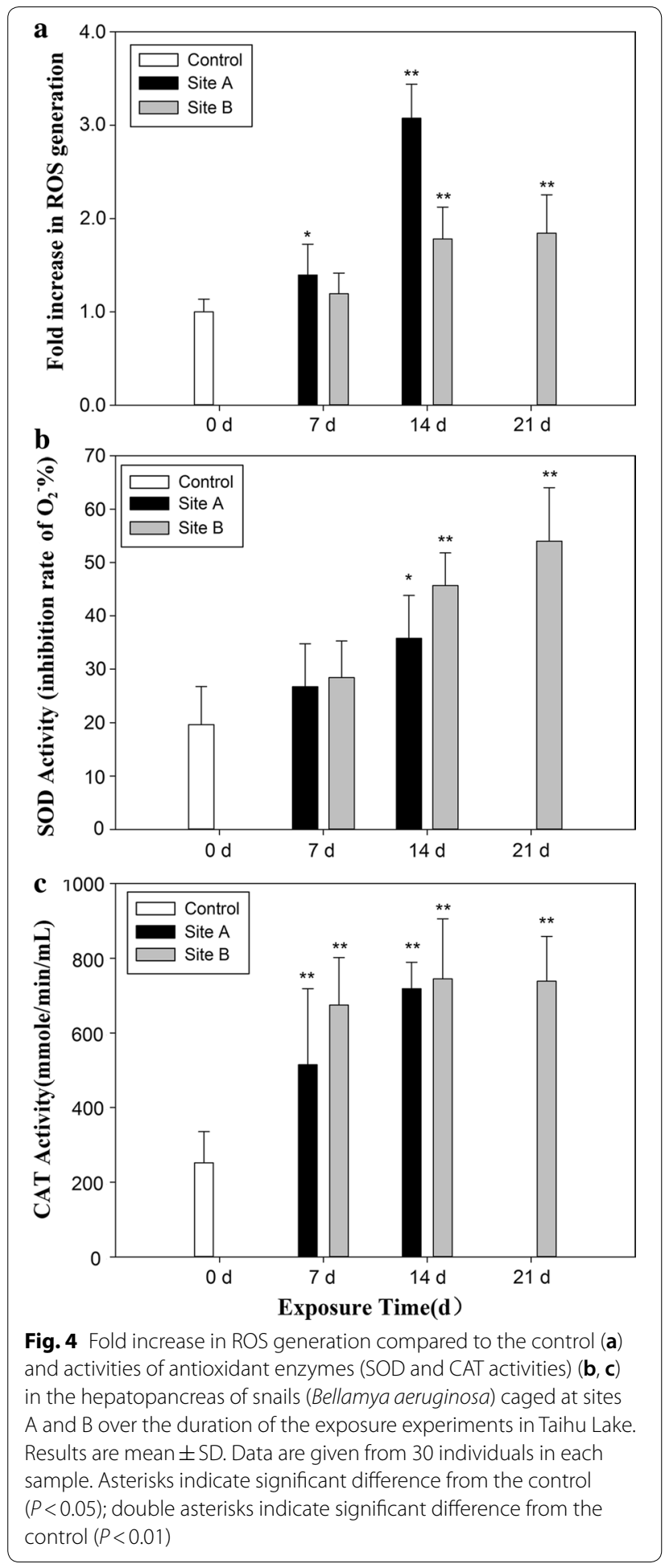

\section{Oxidative stress}

During the initial 14 days of exposure, levels of LPO and PCC in the hepatopancreas of caged snails at both sites increased with the increasing exposure time (Fig. 5).

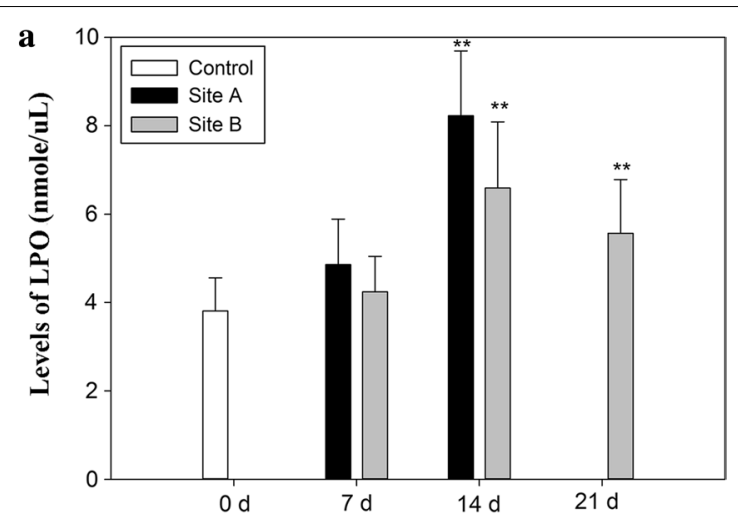

b

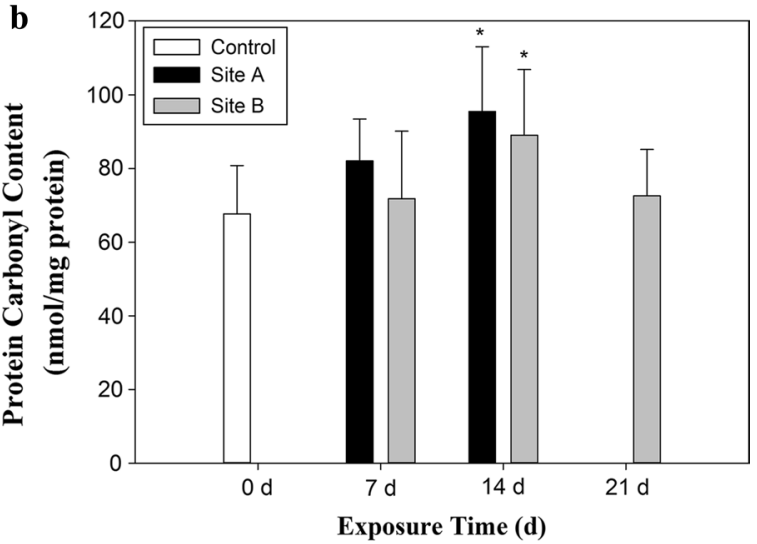

Fig. 5 Oxidative effects [the levels of LPO (a), PCC (b)] in the hepatopancreas of snails (Bellamya aeruginosa) caged at sites A and B over the duration of the exposure experiments in Taihu Lake. Results are mean $\pm S D$. Data are given from 30 individuals in each sample. Asterisks indicate significant difference from the control $(P<0.05)$; double asterisks indicate significant difference from the control $(P<0.01)$

Significant increases in LPO and PCC levels were observed after exposure for 14 days at both sites compared to the control group $(p<0.01$ and $p<0.05$, respectively). Then the levels of LPO and PCC decreased on day 21 at site B. While LPO was still significantly higher in snails from site $\mathrm{B}$ than the control group $(p<0.01)$, no such difference was observed for the levels of PCC in the hepatopancreas of caged snails after 21 days at this site $(p<0.05)$.

\section{Integrated biomarker response index}

All biochemical biomarkers showed a significant induction in the hepatopancreas of snails as a function of exposure time, with the exception of EROD activity at site A (Fig. 6). The biomarker deviation index $(A)$ of CAT activity was greater than that of all other biomarkers, which indicated that CAT was the most responsive biomarker in this in situ exposure experiment. The IBR values for 


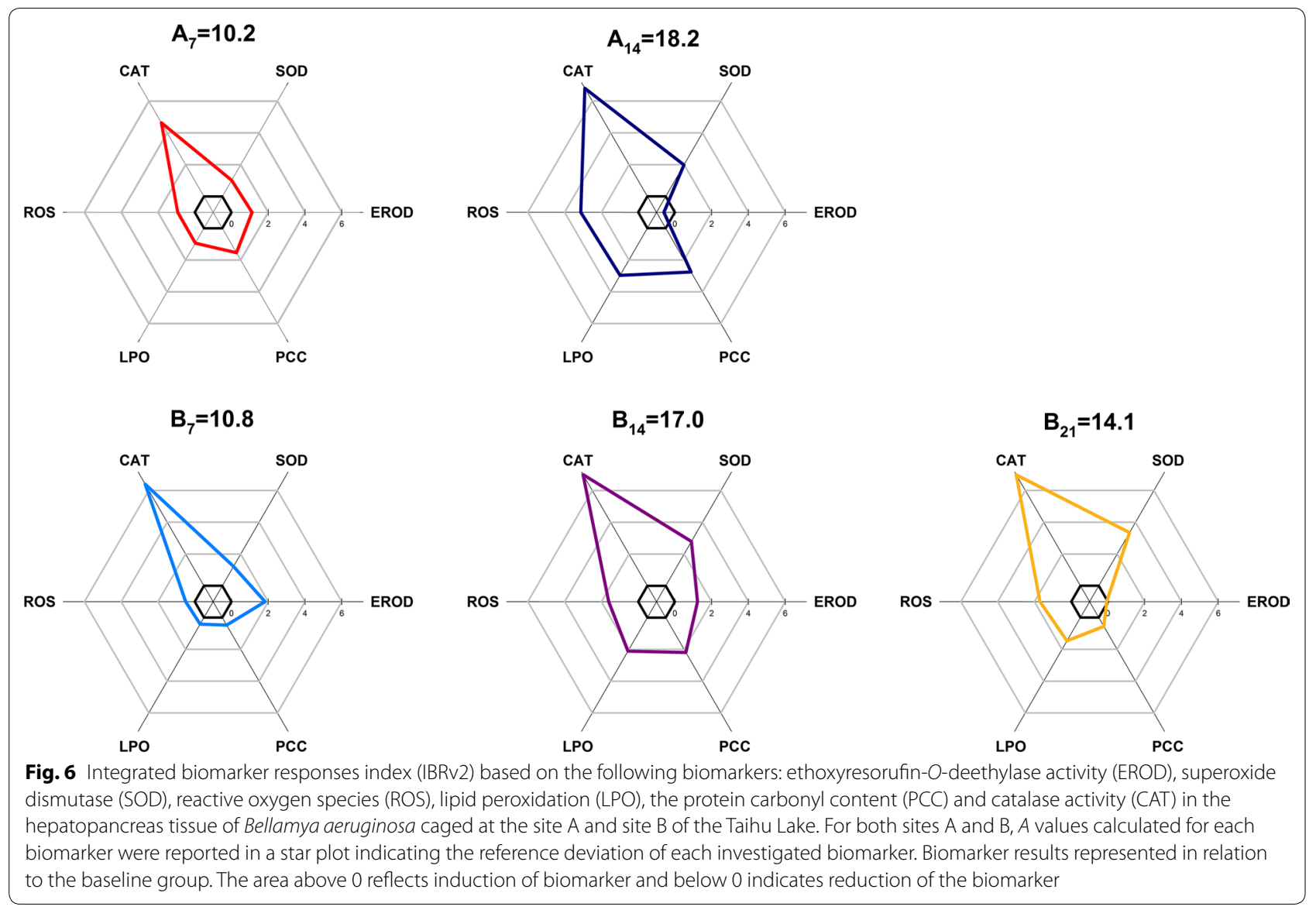

both sites A and B were 10.2 and 10.8 after caging for 7 days, respectively, as minor variations in the analyzed biomarkers were observed. After exposure for 14 days, both caging sites $\mathrm{A}$ and $\mathrm{B}$ showed the highest IBR value $\left(A_{14}=18.2, B_{14}=17.0\right)$. The IBR value for site B decreased to 14.1 after 21 days of exposure.

\section{Discussion}

Biomarkers are important tools for understanding linkages between external contaminant exposures, internal doses and associated potential impacts on health status [12]. In this study, sediment quality of Taihu Lake was assessed by using snails $B$. aeruginosa caged in situ, integrating multiple biochemical responses and chemical analysis.

Analyses of selected contaminants in sediments of Taihu Lake showed that metals $(\mathrm{Cr}, \mathrm{Cu}, \mathrm{Pb}, \mathrm{Ni}, \mathrm{Zn}, \mathrm{Cd}$, As), OCPs, PCBs and PBDEs were detectable at both caging sites. Sediment quality assessment values for freshwater ecosystems in Canada [56] were consulted to evaluate potential risks associated with the observed chemicals. These guidelines consider two effect levels for the characterization of potential toxicological risks, the threshold effect level (TEL) and the probable effect level (PEL). The TEL represents the concentrations of these contaminants below which adverse biological effects only rarely occur, while the PEL represents the concentrations of these contaminants above which adverse biological effects frequently occur [56]. In this study, none of the chemical contaminants detected in sediments from both sites were found to exceed the PEL threshold values (Table 1). However, concentrations of $\mathrm{Cu}, \mathrm{Ni}$ and As in sediments from site A were greater than their TEL. For OCPs, the concentrations of 4,4'-DDE in sediments from site A and site B were found to be above the TEL. Similarly, Zhao et al. [41] demonstrated that high residues of OCPs, including DDTs, HCHs, heptachlors and chlordanes, persisted in surface sediments and B. aeruginosa collected at 20 locations in Taihu Lake. Thus, there is the potential for chemical compounds in sediments from Taihu Lake to have adverse effects on aquatic organisms. In addition, all concentrations of chemicals analyzed in the sediment collected from site A, except for PBDEs, were greater than those at site B. This is in accordance with the result that the survival rate of $B$. aeruginosa caged at site A was lower than that of snails caged at site B after different 
exposure times ( 7 and 14 days), indicating that B. aeruginos $a$ was a relatively sensitive species for biomonitoring in Taihu Lake.

Xenobiotics, especially lipophilic pollutants, can induce adaptive changes in exposed organisms such as induction of phase I enzymes that can oxidize xenobiotics to make them more polar, and thus allow them to be conjugated and excreted. In this study, the mixture of contaminants in sediments of Taihu Lake significantly induced EROD activity in hepatopancreas tissues of snails from both sites after exposure for 7 days. Dioxin-like contaminants, including some PCBs [57], certain polycyclic aromatic hydrocarbons (PAHs) [58] and polychlorinated dibenzo$p$-dioxins and dibenzofurans (PCDD/Fs) [12] have been reported to activate the aryl hydorcarbon receptor, which results in the induction of EROD activity. Dickerson et al. [59] also demonstrated that 4'4-DDE could cause a dosedependent increase in EROD activity in the deer mouse. After exposure for 14 days, there was no significant difference in the EROD activity between the caged snails at both sites and the control, which indicated an adaptation of the caged snails for the contaminated sediments at both sites in Taihu Lake.

Pollutants such as PCBs, lindane and certain heavy metals are important triggers of oxidative stress and the formation of ROS in biological systems [60, 61]. In this study, increased ROS levels were observed in hepatopancreas of caged snails at both sites (Fig. 4), indicating exposure to compounds that cause oxidative stress. Antioxidant enzymes can be induced by enhanced production of ROS as a protective mechanism against oxidative stress, or they can be inhibited when deficiency of the system occurs, suggesting toxicity [62]. In this study, significant increase in oxidative stress as measured by ROS concentrations as well as LPO and PCC occurred in snails exposed at both sampling locations. In parallel, significant increases in SOD and CAT activities were observed, which suggested an adaptive response of the snails inhabiting contaminated sites in Taihu Lake. One possible reason for this increase could be the elevated concentrations of metals including $\mathrm{Cu}, \mathrm{Ni}$ and As, which exceeded TEL values. In an earlier study, Ma et al. [22] found that hepatopancreatic SOD and CAT activities in $B$. aeruginosa were significantly increased after exposure to $51 \mathrm{mg} / \mathrm{kg}$ of $\mathrm{Cu}$ for 28 days. These concentrations were similar to those measured during our study $(\mathrm{Cu}$ concentrations ranged between 17.7 and $39.5 \mathrm{mg} / \mathrm{kg}$ ). Thus, together with the other elements measured in sediments from Taihu Lake, we hypothesize that metals were likely to have caused the oxidative stress observed in caged snails during the exposure.

Lipid peroxidation is the process of oxidative degradation of lipids, which is regarded as a measure of oxidative stress induced by environmental pollutants including heavy metals and wide ranges of organic pollutants [63, 64]. In addition, proteins can be attacked by ROS, which will lead to the formation of carbonyl, a process that is non-reversible and causes a conformational change of proteins [65]. Such changes will reduce catalytic activity in enzymes and ultimately result in breakdown of proteins [66]. In this study, the levels of LPO and PCC in the hepatopancreas of caged snails at both sites significantly increased after exposure for 14 days compared to the control group. The temporal variation of LPO and PCC levels indicated that oxidative stress was induced by contaminants in sediments. LPO and PCC levels in the hepatopancreas of the caged snails at site $\mathrm{B}$ were ameliorated at the later time point of 21 days compared with 14 days, which might be partly due to the increased biochemical defense responses (SOD and CAT) observed in snails at this site. The decrease in both LPO and PCC levels on day 21 indicated an adaptation of the caged snails to the exposure to the environmental conditions in Taihu Lake.

Variations in biochemical biomarkers depend on food availability and spawning period besides exposure to pollutants [67]. Preliminary experiments showed that the inter-individual variations of measured biomarker responses in the basal group were relatively low. As there was enough organic matter in the sediments of Taihu Lake, B. aeruginosa could get enough food during the caging experiment [68]. Xiong et al. [69] have also demonstrated that the CAT activities of $B$. aeruginosa increased in Suzhou Creek for 0, 15 and 30 days and did not show significant difference $(p<0.05)$. Abiotic factors such as temperature, salinity and dissolved oxygen content also influence biomarker responses in an organism [70]. The analysis of water quality revealed no variations between the two caging sites, with values within the normal range for this environment. So abiotic factors may have the same influence on snails caged in two sites. However, possible variations in some specific biomarker responses could not be avoided in the field study [13] So the combination of biomarkers could give a comprehensive picture and provides better insights to study the effects of pollutants.

The Integrated Biomarker Response Index (IBRv2) has been found capable of discriminating scores to describe toxically induced stress based on the specific responses of a number of biomarkers across different sampling sites [27]. In this study, it was used as a tool for the visualization of biological effects of contaminants on snails caged at both sites in Taihu Lake. Several biomarkers exhibited a response that was induced or inhibited as a function of sampling site, and spatial arrangement of these biomarkers in the radar chart allowed visualizing the most 
sensitive biomarkers in the evaluation [71]. From the radar chart of IBR (Fig. 6), CAT activity was the most responsive biomarker compared with other multiple biomarkers in this study. CAT is an important enzyme in antioxidant defense systems protecting animals from oxidative stress $[10,33]$ and has been studied in B. aeruginosa [22] and land snails (Theba pisana) [72]. In general, the IBR index (stress index) increased from day 7 to day 14 of the exposure and decreased at day 21 , showing that environmental stress effects in $B$. aeruginosa initially increased and then weakened, which might be an adaptation mechanism for B. aeruginosa to toxic effects of environmental contaminants. The IBR values were higher in animals from site $\mathrm{A}$ on the 14th day of exposure compared to site B, indicating that site A had a greater impact on B. aeruginosa. As higher contamination levels of metals, OCPs and PCBs were found in the sediments collected from site A compared to site B, the IBR index proved to be in agreement with the levels of environmental contamination in different sediments from Taihu Lake. Thus, it could be inferred that the integration of multiple biomarker responses found in caged snails could reflect the contamination levels measured at different sites and used as an efficient biomonitoring approach $[27,34]$. However, comparisons among larger numbers of diverse sites are required to further validate the IBR as a predictive tool to categorize the contamination levels of sediments.

\section{Conclusion}

The biochemical responses in caged snails deployed at two sites in Taihu Lake as well as the chemical analysis of selected organic and inorganic pollutants indicated significant anthropogenic pollution and potential risks to resident organisms. Multiple biomarkers including EROD, ROS, SOD, CAT, LPO and PCC were induced during caging exposure experiment. The IBRv2 results showed that the CAT activity was the most responsive biomarker. The results of the biochemical biomarkers in B. aeruginosa were consistent with the chemical contamination in the sediments of the lake, indicating that in situ exposures with caged snails can serve as an efficient biomonitoring approach to evaluate sediment quality.

\section{Additional file}

Additional file 1: Table S1. Chemical analysis of surrogate sediments used in the laboratory culture of Bellamya aeruginosa. Text S1. Organic pollutants.

\section{Authors' contributions}

LW conceived and designed the experiments. QL wrote the manuscript. QL and MW made contributions to the biochemical analysis. LD and YQ made contributions to the chemical analysis. TM, MB, ÅB and JZ gave great suggestions on the design and operation of the caging experiments. $\mathrm{LC}$ and $\mathrm{MH}$ made substantial contributions to the interpretation of data and the revision of the manuscript. All authors read and edited the manuscript and agree with its publication in a scientific journal. All authors read and approved the final manuscript.

\section{Author details \\ ${ }^{1}$ State Key Laboratory of Pollution Control and Resource Reuse, College of Environmental Science and Engineering, Tongji University, Shang- hai 200092, China. ${ }^{2}$ College of Biology and Environmental Sciences, Jishou University, Jishou 416000, China. ${ }^{3}$ Department of Environmental Science and Analytical Chemistry, Stockholm University, Svante Arrhenius väg 8, SE-11418 Stockholm, Sweden. ${ }^{4}$ Swedish Toxicology Sciences Research Center (Swetox), Forskargatan 20, 15136 Södertälje, Sweden. ${ }^{5}$ School of the Environ- ment \& Sustainability and Toxicology Centre, University of Saskatchewan, 44 Campus Drive, Saskatoon SK S7N 5B3, Canada.}

\section{Acknowledgements}

The authors are grateful to the Jiangsu water quality and cyanobacteria field multi-observation station for Taihu Lake for providing data of water quality and Prof. Dr. Elena Gorokhova of Department of Environmental Science and Analytical Chemistry, Stockholm University, for her suggestions on the caging exposure design.

\section{Competing interests}

The authors declare that they have no competing interests.

\section{Availability of data and materials}

The datasets supporting the conclusions of this article are included within the article and its additional file.

\section{Consent for publication}

Not applicable.

Ethics approval and consent to participate

Not applicable.

\section{Funding}

This work was supported by a grant from the National Natural Science Foundation of China (No. 41101499), the VR (Swedish Research Council) Research Cooperation China project (No. 63920136913), the State Key Laboratory of Pollution Control and Resource Reuse Foundation (No. PCRRE16011), and the China Scholarship Council. MH has been supported by the Canada Research Chair program.

\section{Publisher's Note}

Springer Nature remains neutral with regard to jurisdictional claims in published maps and institutional affiliations.

Received: 3 July 2018 Accepted: 29 August 2018

Published online: 11 September 2018

\section{References}

1. Liu GQ, Zhang G, Jin ZD, Li J (2009) Sedimentary record of hydrophobic organic compounds in relation to regional economic development: a study of Taihu Lake, East China. Environ Pollut 157:2994-3000

2. Yan ZH, Yang XF, Lu GH, Liu JC, Xie ZX, Wu DH (2014) Potential environmental implications of emerging organic contaminants in Taihu Lake, China: comparison of two ecotoxicological assessment approaches. Sci Total Environ 470:171-179

3. Hartwell SI, Hameedi MJ, Pait AS (2011) Empirical assessment of incorporating sediment quality triad data into a single index to distinguish dominant stressors between sites. Environ Monit Assess 174:605-623 
4. Cesar A, Choueri RB, Riba I, Morales-Caselles C, Pereira CDS, Santos AD, Abessa DMS, DelValls TA (2007) Comparative sediment quality assessment in different littoral ecosystems from Spain (Gulf of Cadiz) and Brazil (Santos and São Vicente estuarine system). Environ Int 33:429-435

5. Brinkmann M, Hudjetz S, Kammann U, Hennig M, Kuckelkorn J, Chinoraks M, Cofalla C, Wiseman S, Geisy JP, Schäffer A, Hecker M, Wölz J, Schüttrumpf H, Hollert H (2013) How flood events affect rainbow trout: evidence of a biomarker cascade in rainbow trout after exposure to PAH contaminated sediment suspensions. Aquat Toxicol 128-129:13-24

6. Chapman PM (1995) Sediment quality assessment: status and outlook. J Aquat Ecosyst Health 4:183-194

7. Hallare AV, Seiler TB, Hollert H (2011) The versatile, changing, and advancing roles of fish in sediment toxicity assessment -a review. J Soils Sediments 11:141-173

8. Burton GA, Greenberg MS, Rowland CD, Irvine CA, Lavoie DR, Brooker JA, Moore L, Raymer DFN, McWilliam RA (2005) In situ exposures using caged organisms: a multi-compartment approach to detect aquatic toxicity and bioaccumulation. Environ Pollut 134:133-144

9. Klobučar GIV, Štambuk A, Pavlica M, Perić MS, Hackenberger BK, Hylland K (2010) Genotoxicity monitoring of freshwater environments using caged carp (Cyprinus carpio). Ecotoxicology 19:77-84

10. Kerambrun E, Sanchez W, Henry F, Amara R (2011) Are biochemical biomarker responses related to physiological performance of juvenile sea bass (Dicentrarchus labrax) and turbot (Scophthalmus maximus) caged in a polluted harbour? Comp Biochem Phys C 154:187-195

11. Bocchetti R, Fattorini D, Pisanelli B, Macchia S, Oliviero L, Pilato F, Pellegrini D, Regoli F (2008) Contaminant accumulation and biomarker responses in caged mussels, Mytilus galloprovincialis, to evaluate bioavailability and toxicological effects of remobilized chemicals during dredging and disposal operations in harbour areas. Aquat Toxicol 89:257-266

12. Maranho LA, André C, DelValls TA, Gagné F, Martín-Díaz ML (2015) In situ evaluation of wastewater discharges and the bioavailability of contaminants to marine biota. Sci Total Environ 538:876-887

13. Liu X, Wang WX (2016) Time changes in biomarker responses in two species of oyster transplanted into a metal contaminated estuary. Sci Total Environ 544:281-290

14. Klobučar GIV, Malev O, Šrut M, Štambuk A, Lorenzon S, Cvetković Ž, Ferrero EA, Maguire I (2012) Genotoxicity monitoring of freshwater environments using caged crayfish (Astacus leptodactylus). Chemosphere 87:62-67

15. Lebrun JD, Geffard O, Urien N, François A, Uher E, Fechner LC (2015) Seasonal variability and inter-species comparison of metal bioaccumulation in caged gammarids under urban diffuse contamination gradient: implications for biomonitoring investigations. Sci Total Environ 511:501-508

16. Schmitt C, Vogt C, Van Ballaer B, Brix R, Suetens A, Schmitt-Jansen M, De Deckere E (2010) In situ cage experiments with Potamopyrgus antipodarum - a novel tool for real life exposure assessment in freshwater ecosystems. Ecotoxicol Environ Saf 73:1574-1579

17. Gust M, Gagné F, Berlioz-Barbier A, Besse JP, Buronfosse T, Tournier M, Tutundjian R, Garric J, Cren-Olivé C (2014) Caged mudsnail Potamopyrgus antipodarum (Gray) as an integrated field biomonitoring tool: exposure assessment and reprotoxic effects of water column contamination. Water Res 54:222-236

18. Ramos-Gómez J, Martín-Díaz ML, Rodríquez A, Riba I, Delvalls TA (2008) In situ evaluation of sediment toxicity in Guadalete Estuary (SW Spain) after exposure of caged Arenicola marina. Environ Toxicol 23:643-651

19. Wiramanaden CIE, Orr PL, Russel CK (2015) Assessment of radium-226 bioavailability and bioaccumulation downstream of decommissioned uranium operations, using the caged oligochaete (Lumbriculus variegatus). Environ Toxicol Chem 34:507-517

20. Oikari A (2006) Caging techniques for field exposures of fish to chemical contaminants. Aquat Toxicol 78:370-381

21. Oetken M, Nentwig G, Loffler D, Ternes T, Oehlmann J (2005) Effects of pharmaceuticals on aquatic invertebrates. Part I. The antiepileptic drug carbamazepine. Arch Environ Contam Toxicol 49:353-361

22. Ma TW, Gong SJ, Zhou K, Zhu C, Deng KD, Luo QH, Wang ZJ (2010) Laboratory culture of the freshwater benthic gastropod Bellamya aeruginosa (Reeve) and its utility as a test species for sediment toxicity. J Environ Sci-China 22:304-313
23. Liu YY, Zhang WZ, Wang YX (1993) Medical Malacology. China Ocean Press, Beijing

24. Yu T, Zhang Y, Hu XN, Meng W (2012) Distribution and bioaccumulation of heavy metals in aquatic organisms of different trophic levels and potential health risk assessment from Taihu lake, China. Ecotoxicol Environ Saf 81:55-64

25. Wang ZS, Yan CZ, Yan YJ, Chi QQ (2012) Integrated assessment of biomarker responses in caged shrimps (Litopenaeus vannamei) exposed to complex contaminants from the Maluan Bay of China. Ecotoxicology 21:869-881

26. Wernersson AS, Carere M, Maggi C, Tusil P, Soldan P, James A, Sanchez W, Dulio V, Broeg K, Reifferscheid G, Buchinger S, Maas H, Grinten EVD, O’Toole S, Ausili A, Manfra L, Marziali L, Polesello S, Lacchetti I, Mancini L, Lilja K, Linderoth M, Lundeberg T, Fjällborg B, Porsbring T, Larsson DGJ, Bengtsson-Palme J, Förlin L, Kienle C, Kunz P, Vermeirssen E, Werner I, Robinson CD, Lyons B, Katsiadaki I, Whalley C, Haan KD, Messiaen M, Clayton H, Lettieri T, Carvalho RN, Gawlik BM, Hollert H, Paolo CD, Brack W, Kammann U, Kase R (2015) The European technical report on aquatic effect-based monitoring tools under the water framework directive. Environ Sci Eur 27:7

27. Vieira CED, Costa PG, Lunardelli B, de Oliveira LF, da Costa Cabrera L, Risso WE, Primel EG, Meletti PC, Fillmann G, Martinez CB (2016) Multiple biomarker responses in Prochilodus lineatus subjected to short-term in situ exposure to streams from agricultural areas in Southern Brazil. Sci Total Environ 542:44-56

28. Cazenave J, Bacchetta C, Parma MJ, Scarabotti PA, Wunderlin DA (2009) Multiple biomarkers responses in Prochilodus lineatus allowed assessing changes in the water quality of Salado River basin (Santa Fe, Argentina). Environ Pollut 157:3025-3033

29. Gorinstein S, Moncheva S, Katrich E, Toledo F, Arancibia P, Goshev I, Trakhtenberg S (2003) Antioxidants in the black mussel (Mytilus galloprovincialis) as an indicator of Black Sea coastal pollution. Mar Pollut Bull 46:1317-1325

30. Manduzio H, Monsinjon T, Rocher B, Leboulenger F, Galap C (2003) Characterization of an inducible isoform of the $\mathrm{Cu} / \mathrm{Zn}$ superoxide dismutase in the blue mussel Mytilus edulis. Aquat Toxicol 64:73-83

31. Almeida EAD, Bainy ACD, de Melo Loureiro AP, Martinez GR, Miyamoto S, Onuki J, Barbosa LF, Garcia CCM, Prado FM, Ronsein GE, Sigolo CA, Brochini CB, Martins AMG, de Medeiros MHG, Mascio PD (2007) Oxidative stress in Perna perna and other bivalves as indicators of environmental stress in the Brazilian marine environment: antioxidants, lipid peroxidation and DNA damage. Comp Biochem Physiol A Mol Integr Physiol 146:588-600

32. Beliaeff B, Burgeot T (2002) Integrated biomarker response: a useful tool for ecological risk assessment. Environ Toxicol Chem 21:1316-1322

33. Damiens G, Gnassia-Barelli M, Loquès F, Roméo M, Salbert V (2007) Integrated biomarker response index as a useful tool for environmental assessment evaluated using transplanted mussels. Chemosphere 66:574-583

34. Serafim A, Company R, Lopes B, Fonseca VF, França S, Vasconcelos RP, Vasconcelos MJ, Cabral HN (2012) Application of an integrated biomarker response index (IBR) to assess temporal variation of environmental quality in two Portuquese aquatic systems. Ecol Indic 19:215-225

35. Sanchez W, Burgeot T, Porcher J (2013) A novel "integrated biomarker response" calculation based on reference deviation concept. Environ Sci Pollut Res 20:2721-2725

36. YuT, Zhang Y, Wu FC, Meng W (2013) Six-decade change in water chemistry of large freshwater Lake Taihu, China. Environ Sci Technol 47:9093-9101

37. Li D, Wu NC, Tang S, Su GY, Li XW, Zhang Y, Wang GX, Zhang JY, Liu HL, Hecker M, Geisy GP, Yu HX (2018) Factors associated with blooms of cyanobacteria in a large shallow lake, China. Environ Sci Eur 30:27

38. Schmidt KR, Beek T, Dai XH, Dong BZ, Dopp E, Eichinger F, Hammers-Wirtz M, Haußmann R, Holbach A, Hollert H, Illgen M, Jiang X, Koehler J, Koester S, Korth A, Kueppers S, Li AL, Lohmann M, Moldaenke C, Norra S, Qin BQ, Qin YW, Reese M, Riehle E, Santiago-Schuebel B, Schaefer C, Simon A, Song YH, Staaks C, Steinhardt J, Subklew G, Tao T, Wu TF, Yin DQ, Zhao FF, Zheng BH, Zhou MY, Zou H, Zuo J, Tiehm A (2016) Since 2015 the SinoGerman research project SIGN supports water quality improvement in the Taihu region, China. Environ Sci Eur 28:24 
39. Floehr T, Xiao HX, Scholz-Starke B, Wu LL, Hou JL, Yin DQ, Zhang XW, Ji R Yuan XZ, Ottermanns R, Roß-Nickoll M, Schäffer A, Hollert H (2013) Solution by dilution? - a review on the pollution status of the Yangtze River. Environ Sci Pollut Res 20:6934-6971

40. Yin HB, Gao YN, Fan CX (2011) Distribution, sources and ecological risk assessment of heavy metals in surface sediments from Lake Taihu, China. Environ Res Lett 6:044012

41. Zhao ZH, Zhang L, Wu JL, Fan CX (2009) Distribution and bioaccumulation of organochlorine pesticides in surface sediments and benthic organisms from Taihu Lake, China. Chemosphere 77:1191-1198

42. Zhang QH, Jiang GB (2005) Polychlorinated dibenzo-p-dioxins/furans and polychlorinated biphenyls in sediments and aquatic organisms from the Taihu Lake, China. Chemosphere 61:314-322

43. Ma TW, Gong SJ, Tian B (2017) Effects of sediment-associated CuO nanoparticles on Cu bioaccumulation and oxidative stress responses in freshwater snail Bellamya aeruginosa. Sci Total Environ 580:797-804

44. Qin $B Q$, Xu PZ, Wu QL, Luo LC, Zhang YL (2007) Environmental issues of Lake Taihu, China. Hydrobiologia 581:3-14

45. Morales-Caselles C, Martín-Díaz ML, Riba I, Sarasquete C, DelValls TÁ (2008) Sublethal responses in caged organisms exposed to sediments affected by oil spills. Chemosphere 72:819-825

46. Vieira CED, Costa PG, Cabrera LC, Primel EG, Fillmann G, Bianchini A, Martinez CBDR (2017) A comparative approach using biomarkers in feral and caged Neotropical fish: implications for biomonitoring freshwater ecosystems in agricultural areas. Sci Total Environ 586:598-609

47. USEPA (1995) SW-846 EPA Method 3052. Microwave assisted acid digestion of siliceous and organically based matrices. In: Test Methods for Evaluating Solid Waste, 3rd Edition, 3rd Update US Environmental Protection Agency, Washington, DC

48. Yang J, Meng XZ, Duan YP, Liu LZ, Chen L, Cheng HF (2014) Spatial distributions and sources of heavy metals in sediment from public park in Shanghai, the Yangtze River Delta. Appl Geochem 44:54-60

49. Yin G, Asplund L, Qiu Y, Zhou Y, Wang H, Yao Z, Jiang J, Bergman $\AA$ (2015) Chlorinated and brominated organic pollutants in shellfish from the Yellow Sea and East China Sea. Environ Sci Pollut Res 22:1713-1722

50. Zhang G, Parker A, House A, Mai B, Li X, Kang Y, Wang Z (2002) Sedimentary records of DDT and $\mathrm{HCH}$ in the Pearl river Delta, South China. Environ Sci Technol 36:3671-3677

51. Mai BX, Chen SJ, Luo XJ, Chen LG, Yang QS, Sheng GY, Peng PA, Fu JM, Zeng EY (2005) Distribution of polybrominated diphenyl ethers in sediments of the Pearl river delta and adjacent South China sea. Environ Sci Technol 39:3521-3527

52. Gao SH, Chen J, Shen ZY, Liu H, Chen YX (2013) Seasonal and spatial distributions and possible sources of polychlorinated biphenyls in surface sediments of Yangtze Estuary, China. Chemosphere 91:809-816

53. Bradford MM (1976) A rapid and sensitive method for the quantitation of microgram quantities of protein utilizing the principle of protein-dye binding. Anal Biochem 72:248-254

54. Burke MD, Mayer RT (1974) Ethoxyresorufin: direct fluorimetric assay of a microsomal O-dealkylation which is preferentially inducible by 3-methylcholanthrene. Drug Metab Dispos 2:583-588

55. Pacheco M, Santos MA (1998) Induction of liver EROD and erythrocytic nuclear abnormalities by cyclophosphamide and PAHs in Anguilla anguillaL. Ecotoxicol Environ Saf 40:71-76

56. Smith SL, MacDonald DD, Keenleyside KA, Ingersoll CG, Field J (1996) A preliminary evaluation of sediment quality assessment values for freshwater ecosystems. J Great Lakes Res 22:624-638

57. Couillard CM, Lebeuf M, Ikonomou MG, Poirier GG, Cretney WJ (2005) Low hepatic ethoxyresorufin-o-deethylase activity correlates with high organochlorine concentrations in Atlantic tomcod from the Canadian east coast. Environ Toxicol Chem 24:2459-2469

58. Cappello T, Maisano M, D'Agata A, Natalotto A, Mauceri A, Fasulo S (2013) Effects of environmental pollution in caged mussels (Mytilus galloprovincialis). Mar Environ Res 91:52-60
59. Dickerson RL, McMurry CS, Smith EE, Taylor MD, Nowell SA, Frame LT (1999) Modulation of endocrine pathways by 4,4'-DDE in the deer mouse Peromyscus maniculatus. Sci Total Environ 233:97-108

60. Livingstone DR, Mitchelmore CL, O'hara SCM, Lemaire P, Sturve J, Förlin L (2000) Increased potential for NAD(P)H-dependent reactive oxygen species production of hepatic subcellular fractions of fish species with in vivo exposure to contaminants. Mar Environ Res 50:57-60

61. Livingstone DR (2001) Contaminant-stimulated reactive oxygen species production and oxidative damage in aquatic organisms. Mar Pollut Bull 42:656-666

62. Tsangaris C, Cotou E, Papathanassiou E, Nicolaidou A (2010) Assessment of contaminant impacts in a semi-enclosed estuary (Amvrakikos Gulf, NW Greece): bioenergetics and biochemical biomarkers in mussels. Environ Monit Assess 161:259-269

63. Valavanidis A, Vlahogianni T, Dassenakis M, Scoullos M (2006) Molecular biomarkers of oxidative stress in aquatic organisms in relation to toxic environmental pollutants. Ecotoxicol Environ Saf 64:178-189

64. Ramos-Gómez J, Martins M, Raimundo J, Vale C, Martín-Díaz ML, DelValls TÁ (2011) Validation of Arenicola marina in field toxicity bioassays using benthic cages: biomarkers as tools for assessing sediment quality. Mar Pollut Bull 62:1538-1549

65. Gopalakrishnan S, Nai Z, Thilagam H, Bei C, Ding J, Wang XH, Wang WX, Ke CH, Giesy JP, Zhang XW, Wang KJ (2011) Biochemical responses and DNA damage in red sea bream from coastal Fujian Province, China. Ecotoxicol Environ Saf 74:1526-1535

66. Zhang $X$, Yang F, Zhang $X, X u Y$, Liao T, Song $S$, Wang H (2008) Induction of hepatic enzymes and oxidative stress in Chinese rare minnow (Gobiocypris rarus) exposed to waterborne hexabromocyclododecane (HBCDD). Aquat Toxicol 86:4-11

67. Hagger JA, Lowe D, Dissanayake A, Jones MB, Galloway TS (2010) The influence of seasonality on biomarker responses in Mytilus edulis. Ecotoxicology 19:953-962

68. Zhu MY, Zhu GW, Zhao LL, Yao X, Zhang YL, Gao G, Qin BQ (2013) Influence of algal bloom degradation on nutrient release at the sedimentwater interface in Lake Taihu, China. Environ Sci Pollut Res 20:1803-1811

69. Xiong YQ, You WH (2002) Preliminary study on effects of SOD and catalase of Bellamya aeruginosa raised in Suzhou Creek. J East China Norm Univ 4:96-101

70. Cailleaud K, Maillet G, Budzinski H, Souissi S, Forget-Leray J (2007) Effects of salinity and temperature on the expression of enzymatic biomarkers in Eurytemora affinis (Calanoida, Copepoda). Comp Biochem Physiol 147A:841-849

71. Vieira CED, Almeida MS, Galindo BA, Pereira L, Martinez CBR (2014) Integrated biomarker response index using a Neotropical fish to assess the water quality in agricultural areas. Neotrop Ichthyol 12:153-164

72. Radwan MA, El-Gendy KS, Gad AF (2010) Biomarkers of oxidative stress in the land snail, Theba pisana for assessing ecotoxicological effects of urban metal pollution. Chemosphere 79:40-46

\section{Submit your manuscript to a SpringerOpen ${ }^{\circ}$ journal and benefit from:}

- Convenient online submission

- Rigorous peer review

- Open access: articles freely available online

- High visibility within the field

- Retaining the copyright to your article

Submit your next manuscript at $\boldsymbol{\nabla}$ springeropen.com 